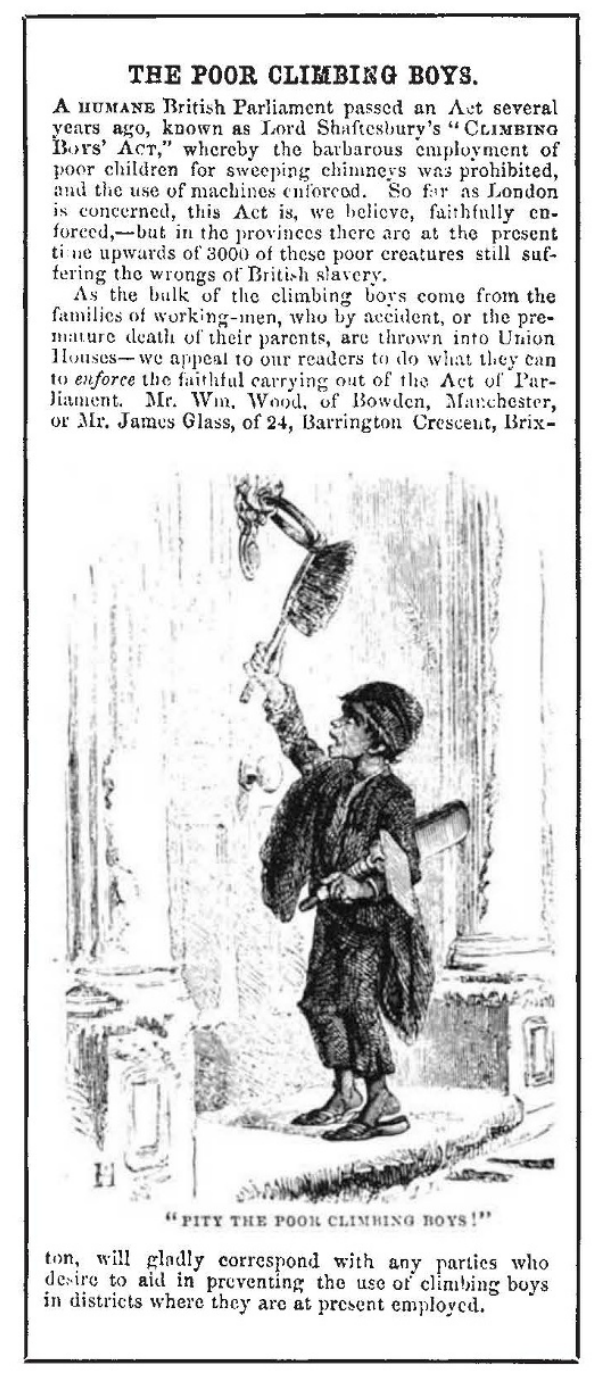

\section{Cancer at work}

Although there has been progress in the treatment of cancer by radiation, surgery, chemotherapy and immunotherapy, it is probable that efforts to prevent the disease have been more rewarding and effective than those made to improve treatment. Some occupational cancers can be prevented when the cause is identified. It is, however, often difficult to find the causes and sometimes even more difficult to remove them when they are known. Two hundred years after Percival Pott made the connection between cancer and the working environment, Professor $E$. Boyland reviews subsequent work on occupational cancers.
D ERCIVAL POTT, FRS, was a surgeon at St Bartholomew's Hospital; his "Chirurgical observations relative to the cataract, the polypus of the nose, the cancer of the scrotum, the different kinds of ruptures and the modification of the toes and feet" was published by Hawes and Collins in Pater-noster Row in 1775. The paper entitled "cancer scroti" describes "a disease as peculiar to a certain set of people which has not, at least to my knowledge, been publicly noticed; I mean the chimney-sweepers' cancer". "The trade call it soot-wart. The disease, in these people, seems to derive its origin from the lodgement of soot in the rugae of the scrotum". He had identified a cause of cancer-a carcinogen active in man. The observations and identification did not stop the exposure of the child chimney sweeps, and Charles Kingsley, who was an active member of the Christian Socialist movement led by Frederick Denison Maurice, described the plights of these child workers in Waterbabies almost a century later.

Pott pointed out that "the subjects are young, in general in good health, at least at first, the disease brought on them by their occupation-all this makes it (at first) a very different case from cancer which appears in an elderly man, whose fluids become acrimonious from time, as well as other causes; or from the same kind of complaint in women who have ceased to menstruate. But be all this as it may, the scrotum is no vital organ, nor can the loss of a part of it ever be attended with ... the smallest degree of inconvenience". He must have perceived the process which is chemical carcinogenesis.

Percival Pott was a modest scholar; as his son-in-law, Sir James Earle, wrote "he often said he began to teach when he had much to learn; and that he was not actuated by that opinionative wisdom which sometimes attends advanced life, after all his study and experience he confessed that he still retained a long list of inquirenda". Samuel Johnson was one of his patients and his portrait painted by Joshua Reynolds hangs in St Bartholomew's Hospital. His epitaph reads "The labours of the ancients were familiar to him; he scorned to teach a science of which he had not traced the growth."

The Romans had chimneys in connection with their hot air heating systems, but in northern Europe chimneys were developed slowly. In mediaeval times hearths in the centre of the living room and vents in the roof were usual. When coal became available as a domestic fuel Count Rumford established the forms and proper relationships of the parts of the chimney. The chimneys which required children to clean them were an English development and the associated disease was more common in England than in continental Europe. It seems probable that chimney sweeps in Germany had some form of protective clothing.

Before Percival Pott, Ramazzini in the de morbis artificum, published in 1700 , considered occupational diseases such as the colic due to lead to which painters, glaziers and plumbers were exposed. Ramazzini had noticed the high incidence of breast cancer in nuns and indicated that this was caused by their occupation.

Following the work of Pott many clinicians reported on the condition. Bell in 1794 described other cases and said it appears obviously to be produced by soot, for it is found that besides chimney sweeps those who are employed in manufacture in which soot enters are occasionally seized by it. James Earle in 1808 recorded a case of a gardener with epithelioma of the left hand on which he had previously hung a pot containing soot used to kill slugs. He saw that skin cancer elsewhere than in the scrotum could be caused by soot. In the edition of the works of Percival Pott, revised by James Earle in 1808, reference was made to an eight-year-old apprentice with scrotal cancer. Often, however, there was a long latent period. Curling in 1856 described a case of a sailor who developed scrotal cancer in the fifth decade of life but who had been brought up as a sweep. In the nineteenth century the disease remained but it was recognised that not all children employed as sweeps developed scrotal cancer.

With the expansion of the Industrial Revolution increasing amounts of oils were used for the lubrication of machines. Before 1850 the oils were mainly of animal origin but later mineral oils were used in much larger quantities. Volkmann in 1875 described occupational skin cancer by tar, paraffin and soot in Germany and in the following year (1876) Bell of Edinburgh described cases of "paraffin cancer" in workers in the Scottish shale oil industry.

As the incidence of chimney sweeps' cancer decreased in the nineteenth century the incidences of scrotal cancer increased among the spinners of the Lancashire cotton industry, the first cases being described in 1887. This "mule spinners' cancer" has decreased in the present century because (1) the cotton industry employs fewer workers, (2) ring spinning machines have replaced the old mule spinners, (3) less carcinogenic oils controlled by specifications are used, and (4) there has been a general improvement in hygiene. Although less common, scrotal cancer 